\title{
EXCRETION OF SODIUM AND POTASSIUM IN HUMAN SWEAT ${ }^{1}$
}

\author{
BY IRVING L. SCHWARTZ AND JØRN HESS THAYSEN \\ (From the Hospital of The Rockefeller Institute for Medical Research, New York, N. Y.)
}

(Submitted for publication August 17, 1955; accepted September 28, 1955)

Most studies of sweat composition have dealt with sweat obtained after a thermal stimulus (1). Such stimulation may influence other organs which in turn may influence the function of the sweat glands. To avoid such secondary effects we have induced a localized flow of sweat by injecting a cholinergic drug into a small area of skin and observed the outflow of water and certain solutes. The techniques employed permitted numerous observations, replication, control of the intensity and localization of the stimulus, and exact quantitation of the response. The studies to be reported below are concerned with the excretion of sodium and potassium in sweat obtained under these conditions. The results are considered in relation to possible functional subdivisions of the process of sweat secretion.

\section{PROCEDURE}

Fifteen men and two women served as subjects. Six were normal, 30 to 35 years of age; eleven, 25 to 50 years of age, had essential hypertension uncomplicated by cardiac or renal failure. In none of the subjects was there evident endocrine disease, edema or dehydration. The tests were started at least two hours after a light breakfast. Unless otherwise noted the patients were on standard diets providing $175 \mathrm{mEq}$. of sodium chloride daily and water ad libitum until the start of the test. During the test the subject remained at rest in bed.

In a typical experiment sweating was induced in symmetrical forearm sites by intradermal injection of B-methylacetylcholine hydrochloride (Mecholyl), $2 \mathrm{mg}$. in $0.5 \mathrm{ml}$. of isotonic saline. The collection of sweat by a standard procedure (2) has been described previously.

In brief, the unit used for collection of sweat consisted of an aluminum ring cemented to the skin and an aluminum cover assembly containing a rubber compression gasket to insure a gas-tight seal. The chamber formed when the lid was fixed into the ring had an internal diameter of $25 \mathrm{~mm}$. and a height of $1 \mathrm{~mm}$. The sweat was absorbed into one or more filter paper discs, its quantity determined by weight and its content of sodium and potassium by flame photometry using lithium as an internal standard.

1 This work was presented in part at the Fall Meeting of the American Physiological Society, Madison, Wisconsin, 1954.
In each experiment there were 5 to 20 consecutive collection periods each lasting from 10 to 30 minutes. In all, 53 experiments were completed and 557 samples of sweat collected and analyzed for sodium. Of this group, 362 samples ( 32 experiments, 9 subjects) were also analyzed for potassium. Most of the collections of sweat were obtained from the proximal medioventral surface of the forearm, while in a few experiments sites on the arms, thighs, abdomen and back were used. During the tests one or more samples of blood were drawn from an antecubital vein, heparinized, centrifuged immediately and the plasma analyzed for sodium and potassium in the same manner as the samples of sweat.

Two experiments served to estimate the precision of the measurements: A solution containing $122 \mathrm{mEq}$. per $\mathrm{L}$. of sodium and $10 \mathrm{mEq}$. per L. of potassium was delivered onto filter paper discs in 20 weighing vessels. Each of five vessels received approximately $0.2 \mathrm{ml}$. of the solution ( $\mathrm{Na} 24 \mu \mathrm{Eq}$., $\mathrm{K} 2.0 \mu \mathrm{Eq}$.) ; five received $0.1 \mathrm{ml}$. ( $\mathrm{Na} 12 \mu$ Eq., $\mathrm{K} 1.0 \mu$ Eq.); five received $0.05 \mathrm{ml}$. (Na $6 \mu \mathrm{Eq} ., \mathrm{K} .0 .5 \mu \mathrm{Eq}$.) ; and the remaining five vessels received $0.025 \mathrm{ml}$. ( $\mathrm{Na} 3 \mu \mathrm{Eq}$., $\mathrm{K} 0.25 \mu \mathrm{Eq}$.). In the second experiment a solution containing $33 \mathrm{mEq}$. of sodium and $10 \mathrm{mEq}$. of potassium per liter was delivered onto discs in 15 weighing vessels. Five of the vessels received $0.05 \mathrm{ml}$. ( $\mathrm{Na} 1.6 \mu \mathrm{Eq}$., $\mathrm{K} 0.5 \mu \mathrm{Eq}$.) five received $0.025 \mathrm{ml}$. ( $\mathrm{Na} 0.8 \mu \mathrm{Eq} ., \mathrm{K} 0.25 \mu \mathrm{Eq}$.) and five received $0.125 \mathrm{ml}$. ( $\mathrm{Na} 0.4 \mu \mathrm{Eq}$., K $0.13 \mu \mathrm{Eq}$.). The size of each sample was measured by weight and the quantity of sodium and potassium determined by flame photometry just as in the routine procedure. The results showed that the recovery became less precise with decrease in the absolute quantities of sodium and potassium brought to analysis (Table I). The recoveries of $3 \mu \mathrm{Eq}$. of sodium and $0.5 \mu$ Eq. of potassium averaged $101 \pm 3.1$ per cent and 101.5 \pm 5.1 per cent respectively. These are the quantities of sodium and potassium that would be encountered in $50 \mathrm{mg}$. of sweat containing $60 \mathrm{mEq}$. per L. of sodium and $10 \mathrm{mEq}$. per L. of potassium.

\section{RESULTS}

\section{Sodium}

The concentration of sodium, $\mathrm{S}_{\mathrm{Na}}$, rose toward a maximum, $S^{\prime}{ }_{N a}$, with increase in the rate of sweating (Figure 1). Over a range of flows from 0.35 to $25.3 \mathrm{gm}$. per $\mathrm{M}^{2}$ min., $\mathrm{S}_{\mathrm{Na}}$ varied from $1.9^{2}$

2 This is the lowest significant value found for $S_{\mathrm{Na}}$; but the fact that still lower values prevailed at times was 
TABLE I

Recovery of known amounts of sodium and potassium from filter paper discs

\begin{tabular}{|c|c|c|c|c|c|c|}
\hline \multirow[b]{2}{*}{ Solution } & \multicolumn{3}{|c|}{ Sodium } & \multicolumn{3}{|c|}{ Potassium } \\
\hline & $\begin{array}{c}\text { Amount of } \mathrm{Na} \\
\text { added } * \mu E q .\end{array}$ & $\begin{array}{l}\text { Per cent } \\
\text { Mean * }\end{array}$ & $\begin{array}{l}\text { Recovered } \\
\text { S.D. }\end{array}$ & $\begin{array}{l}\text { Amount of } \mathrm{K} \\
\text { added * } \mu E q .\end{array}$ & $\begin{array}{l}\text { Per cent } \\
\text { Mean } *\end{array}$ & $\begin{array}{l}\text { Recovered } \\
\text { S.D. }\end{array}$ \\
\hline A & $\begin{array}{c}24.6 \\
12.6 \\
6.11 \\
3.12\end{array}$ & $\begin{array}{l}99.2 \\
102 \\
102 \\
101\end{array}$ & $\begin{array}{l}0.2 \\
2.0 \\
1.8 \\
3.1\end{array}$ & $\begin{array}{l}2.02 \\
1.03 \\
0.50 \\
0.26\end{array}$ & $\begin{array}{l}100 \\
101 \\
105 \\
116\end{array}$ & $\begin{array}{r}2.0 \\
1.0 \\
2.0 \\
14.7\end{array}$ \\
\hline B & $\begin{array}{l}1.79 \\
0.84 \\
0.42\end{array}$ & $\begin{array}{l}95.3 \\
105 \\
120\end{array}$ & $\begin{array}{r}10.0 \\
8.0 \\
15.0\end{array}$ & $\begin{array}{l}0.52 \\
0.25 \\
0.13\end{array}$ & $\begin{array}{r}98 \\
104 \\
123\end{array}$ & $\begin{array}{r}5.3 \\
18.0 \\
22.1\end{array}$ \\
\hline
\end{tabular}

* Average of 5 replicates.

to $103.8 \mathrm{mEq}$. per L., the maximum being well below the concentration in plasma, $\mathrm{P}_{\mathrm{Na}}$. In any one experiment, $\mathrm{P}_{\mathrm{Na}}$ remained constant; in the total of 53 experiments, $\mathrm{P}_{\mathrm{Na}}$ varied between the extremes of 137 to $153 \mathrm{mEq}$. per L. without any systematic relation to the concentration in sweat. The ratio, $\mathrm{S}_{\mathrm{Na}} / \mathrm{P}_{\mathrm{Na}}$, averaged $0.39 \pm 0.20$ with a range from 0.05 to 0.64 .

The rate of excretion of sodium in the sweat, $\mathrm{E}_{\mathrm{Na}}$, a product of both the concentration, $\mathrm{S}_{\mathrm{Na}}$, and the flow, $V$, rose sharply because of increase in both factors. Therefore at high rates of flow the excretion rate approached a linear function of flow, $E_{\mathrm{Na}}=S_{\mathrm{Na}}^{\prime} \mathrm{V}-\mathrm{T}_{\mathrm{Na}}$, where $\mathrm{S}_{\mathrm{Na}}^{\prime}$ and $\mathrm{T}_{\mathrm{Na}}$ are constants (Figure 2).

$\mathrm{S}_{\mathrm{Na}}^{\prime}$ and $\mathrm{T}_{\mathrm{Na}}$ were estimated from the linear re-

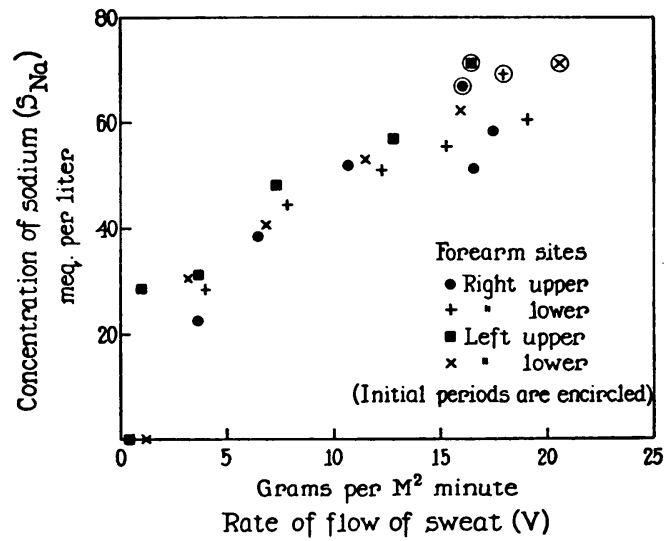

Fig. 1. Relation Between the Concentration of Sodium in Sweat and the Sweating Rate

The data presented are from a typical experiment, each point representing an individual collection period. An encircled point refers only to data from the first collection period at each test site.

evident from the occasional failure of our analytical method to detect any sodium in sweat samples obtained at flow rates of $2 \mathrm{gm}$. per $\mathrm{M}^{2} \mathrm{~min}$. or less.

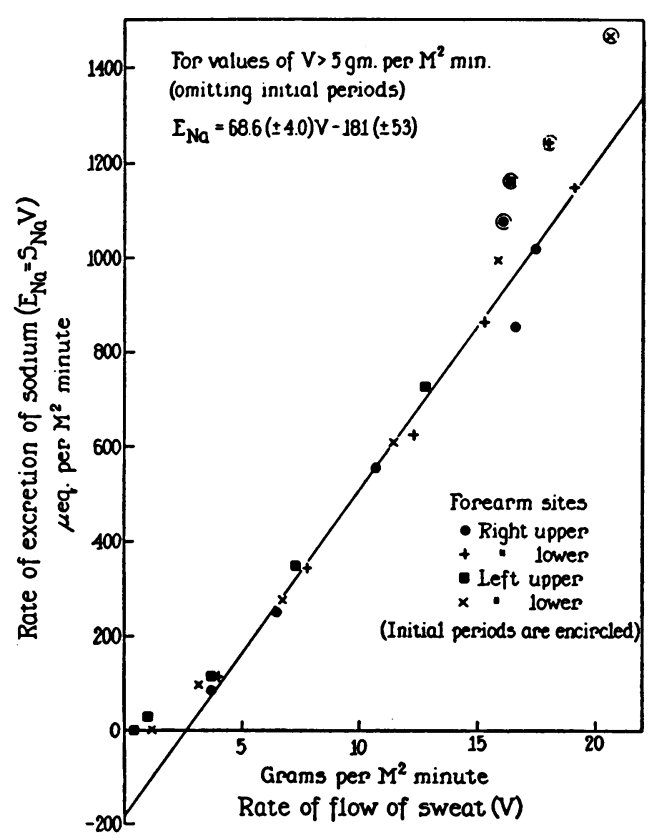

Fig. 2. Relation Between the Rate of Excretion of Sodrum in the Sweat and the Sweating Rate

The data are calculated from the experiment shown in Figure 1. An encircled point refers only to data from the first collection period at each test site.

gressions of $\mathrm{E}_{\mathrm{Na}}$ on $\mathrm{V}$ for values of $\mathrm{V}$ above $5 \mathrm{gm}$. per $\mathrm{M}^{2}$ min., omitting the first period which proved to be atypical (vide infra). Values for $\mathrm{S}_{\mathrm{Na}}^{\prime}$ and $\mathrm{T}_{\mathrm{Na}}$ derived from 25 experiments on seven subjects are given in Table II. $\mathrm{S}_{\mathrm{Na}}^{\prime}$ averaged $56.5 \pm$ $29.1 \mathrm{mEq}$. per L. with a range from 7 to $96 \mathrm{mEq}$. per L.; $\mathrm{T}_{\mathrm{Na}}$ averaged $185 \pm 100 \mu \mathrm{Eq}$. per $\mathrm{M}^{2} \mathrm{~min}$. with a range from 19 to $300 \mu \mathrm{Eq}$. per $\mathrm{M}^{2} \mathrm{~min}$. $\mathrm{S}_{\mathrm{Na}}$ and $\mathrm{T}_{\mathrm{Na}}$ were found to vary greatly from subject to subject but very much less in replicate studies involving the same subject (Table II). The variance of $S^{\prime}{ }_{\mathrm{Na}}$ and $T_{\mathrm{Na}}$ from site to site in the same experiment was significantly less $(p<$ 
0.01) than the variance from experiment to experiment at the same site, indicating that the total variance of these parameters was due chiefly to physiological factors and not to experimental technique.

The concentration of sodium in the sweat of the collection period immediately following the stimulating injection was not related to the sweating rate in the same manner as the concentration of sodium in the sweat of the subsequent collection periods. The point defining the concentration of sodium and the sweating rate of the initial collection period usually fell well above any simple curve fitted to the points defining the concentra- tions of sodium and the rates of flow of sweat of the subsequent periods (Figure 1). In several experiments the sweating rate during the second collection period was the same as or greater than the sweating rate during the initial period; in each of these experiments the concentration of sodium in the initial sample of sweat was invariably higher than the concentration of sodium in the sample of sweat obtained in the following period. This difference proved to be significant $(p<0.01)$.

\section{Potassium}

In general the concentration of potassium in the sweat, $S_{k}$, remained constant as the rate of

TABLE II

Excretion of water, sodium and potassium in sweat after intradermal Mecholyl * $\dagger$

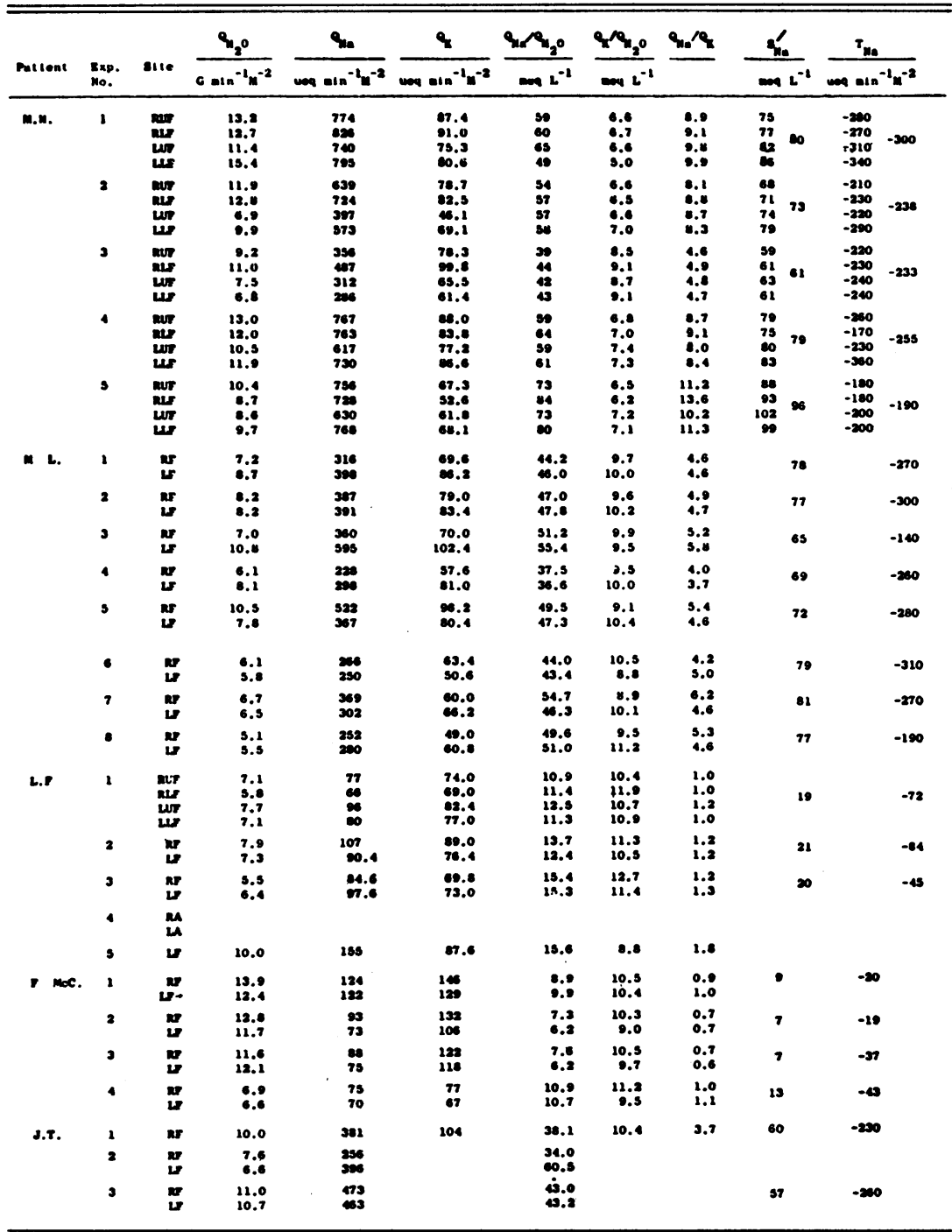


TABLE II.-Continued

\begin{tabular}{|c|c|c|c|c|c|c|c|c|c|c|}
\hline metiont. & $\begin{array}{l}\text { Exp. } \\
\text { mo. }\end{array}$ & sice & $\frac{M_{2} 0}{6 \min ^{-1} m^{-2}}$ & $\frac{9 x}{m=n^{-1} n^{-2}}$ & $\frac{x}{m \sin ^{-1} n^{-2}}$ & $\frac{m-a_{2}{ }^{0}}{m L^{-1}}$ & $\frac{2 m_{2} 0}{m L^{-1}}$ & mon & $\frac{x^{\prime}}{-2^{-1}}$ & $\frac{T_{m}}{m m^{-1} m^{-2}}$ \\
\hline \multirow[t]{6}{*}{ 1.0. } & 2 & $\underset{2 r n}{m m}$ & $\begin{array}{l}3.0 \\
3.0\end{array}$ & ${ }_{105}^{100}$ & & ss.3 & & & & \\
\hline & 2 & $\underset{\mathbf{L r h}}{\mathbf{m}}$ & 3.1 & $\underset{107}{\mathbf{2 0 1}}$ & & $\begin{array}{cc}7.2 \\
60.4\end{array}$ & & & & \\
\hline & 3 & $\mathbf{m i n}_{\mathbf{L T}}^{\mathbf{m n}}$ & $\begin{array}{l}4.1 \\
3.4\end{array}$ & 200 & & ss.? & & & & \\
\hline & 4 & $\operatorname{Tn}_{r(R+L)}(\boldsymbol{L})$ & 3.8 & 2804 & e..5 & $\begin{array}{l}30.1 \\
\infty 0.5\end{array}$ & $\because 4$ & $\begin{array}{l}.8 \\
4.4\end{array}$ & & \\
\hline & $\mathbf{s}$ & $\underset{\mathbf{L T m}}{\mathbf{m}}$ & $\begin{array}{l}6.7 \\
3.2\end{array}$ & $\begin{array}{l}210 \\
140\end{array}$ & 89.4 & $\begin{array}{l}31.4 \\
28.7\end{array}$ & $\begin{array}{l}0.5 \\
0.2\end{array}$ & $\begin{array}{l}\mathbf{3 . 3} \\
\mathbf{3 . 1}\end{array}$ & & \\
\hline & $\bullet$ & 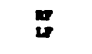 & $\begin{array}{l}3.1 \\
3.4\end{array}$ & $\begin{array}{l}212 \\
246\end{array}$ & $\begin{array}{c}4.6 \\
4.7\end{array}$ & $\begin{array}{l}41.3 \\
45.7\end{array}$ & $\because .8$ & $\begin{array}{l}4.7 \\
3.0\end{array}$ & & \\
\hline 1.8. & 2 & 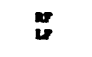 & 3.5 & 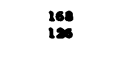 & $\begin{array}{l}30.7 \\
32.8\end{array}$ & $\begin{array}{l}37.7 \\
34.3\end{array}$ & $\therefore .7$ & $\because 4$ & & \\
\hline \multirow[t]{5}{*}{ J. D'A. } & I & 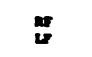 & 3 & $\ddot{91}$ & & $\underset{20.1}{n .1}$ & & & & \\
\hline & 2 & $v$ & 3.4 & 108 & & 31.2 & & & & \\
\hline & 3 & 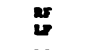 & $\begin{array}{l}4.2 \\
4.1\end{array}$ & 205 & & $\begin{array}{l}40.2 \\
6.0\end{array}$ & & & & \\
\hline & $\bullet$ & 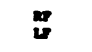 & s.o & $\begin{array}{l}251 \\
203\end{array}$ & & $\begin{array}{l}\text { se.s } \\
\text { so.e }\end{array}$ & & & $n$ & -100 \\
\hline & $\mathbf{s}$ & v & $\begin{array}{l}0.2 \\
0.0\end{array}$ & $m_{m 1}^{202}$ & & $\begin{array}{l}12.6 \\
13.3\end{array}$ & & & so & -140 \\
\hline \multirow[t]{2}{*}{ c.s. } & 1 & 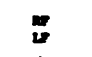 & ::0 & 200 & & ${ }_{30.4}^{\infty}$ & & & $\omega$ & -250 \\
\hline & 2 & $:$ & 4.8 & ${ }_{170}^{200}$ & & $\begin{array}{l}42.8 \\
30.5\end{array}$ & & & & \\
\hline L.b. & 1 & $\pi$ & $\begin{array}{l}2.9 \\
3.3\end{array}$ & 201 & & $\begin{array}{l}\text { es.2 } \\
\text { es.o }\end{array}$ & & & & \\
\hline J.8. & $\begin{array}{l}1 \\
2 \\
3 \\
1 \\
3\end{array}$ & 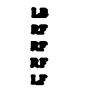 & $\begin{array}{l}4.4 \\
3.5 \\
7.3 \\
3.2 \\
4.6\end{array}$ & $\begin{array}{l}123 \\
182 \\
242 \\
200 \\
135\end{array}$ & & $\begin{array}{l}20.4 \\
330.4 \\
33.0 \\
320.0 \\
20.7\end{array}$ & & & & \\
\hline A.M. & 1 & $u$ & 8.1 & 263 & & 32.0 & & & & \\
\hline n.r. & 1 & $\underset{v}{W}$ & $\begin{array}{l}3.1 \\
4.2\end{array}$ & $\begin{array}{l}167 \\
140\end{array}$ & 30.4 & $\begin{array}{l}33.0 \\
34.1\end{array}$ & :.0 & 4.2 & & \\
\hline v.p. & 1 & 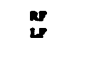 & $\begin{array}{l}2.3 \\
3.0\end{array}$ & $\stackrel{93}{90}$ & & $\begin{array}{l}\mathbf{0 . 6} \\
33.4\end{array}$ & & & & \\
\hline \multirow[t]{3}{*}{ a.r. } & 1 & 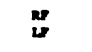 & $\begin{array}{l}2.2 \\
3.5\end{array}$ & $\begin{array}{l}65 \\
97\end{array}$ & & $\underset{23.3}{23.0}$ & & & & \\
\hline & - & 8 & $\begin{array}{l}2.6 \\
2.6\end{array}$ & $\begin{array}{c}64 \\
104\end{array}$ & & 39.3 & & & & \\
\hline & 3 & 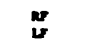 & 1.8 & $\begin{array}{l}19 \\
35\end{array}$ & & $\begin{array}{l}17.1 \\
20.7\end{array}$ & & $!$ & & \\
\hline c.c. & 1 & 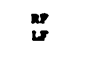 & $\begin{array}{l}2.1 \\
2.0\end{array}$ & 1118 & & $\begin{array}{l}36.0 \\
\text { s6.8 }\end{array}$ & & & & \\
\hline s.r & ' & 8 & li.s & $\begin{array}{l}22 \\
20\end{array}$ & $\begin{array}{l}20.6 \\
0.2\end{array}$ & $\begin{array}{l}11.4 \\
19.2\end{array}$ & $\begin{array}{l}20.3 \\
21.0\end{array}$ & $\begin{array}{l}0.6 \\
0.5\end{array}$ & & \\
\hline
\end{tabular}

* $Q_{\mathrm{H}_{2} \mathrm{O}}, Q_{\mathrm{Na}}$ and $Q_{\mathrm{K}}$ represent total quantities obtained in the serial periods at each site divided by the collection time in minutes and corrected to a standard skin area of $1 \mathrm{M}^{2}$. $\mathrm{S}_{\mathrm{Na}}$ and $\mathrm{T}_{\mathrm{Na}}$ are the slope and intercept, respectively, of the linear regression of the rate of excretion of sodium on the rate of flow of sweat for flows exceeding $5 \mathrm{gm}$. per $\mathrm{M}^{2} \mathrm{~min}$.

† Sodium chloride intake was unrestricted but not administered quantitatively to the six normal subjects: J. T., I. S., I. B., L. D., A. N., and G. C. The hypertensive patients were given sodium chloride in the following amounts daily: $M$. $H$., M. L., J. D'A., C. S., J. S., and N. F., $175 \mathrm{mEq}$; L. F., F. McC., and M. F., 22 mEq.; A. Y., and W. P., $5 \mathrm{mEq}$.

Values for $S_{N a}$ and $T_{N a}$ could be estimated only for the experiments in which the rate of flow of sweat exceeded $5 \mathrm{gm}$. per $\mathrm{M}^{2} \mathrm{~min}$. during at least 3 of the collection periods. In subject, M. H., the high sweating rate permitted estimation of $S^{\prime}{ }_{N a}$ and $T_{N a}$ for each site as well as the average values for each experiment.

$\ddagger R F$-right forearm, LF-left forearm, RUF-right upper forearm, RLFright lower forearm, LUF-left upper forearm, LLF-left lower forearm, A-arm, Th-thigh, B-back. 


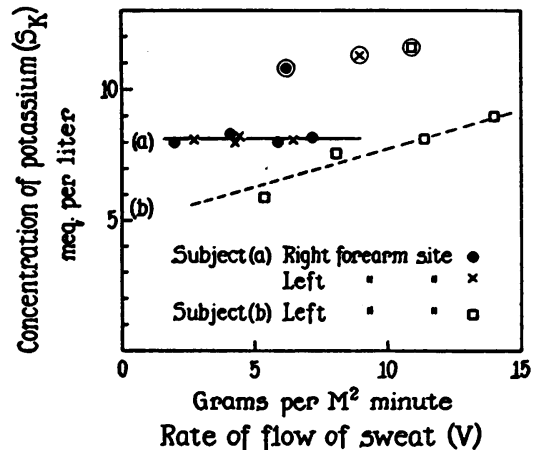

Fig. 3. Relation Between the Concentration of Potassium in the Sweat and the Sweating Rate

(a) Illustrates the relation that is usually observed; (b) illustrates the atypical response. An encircled point refers only to data from the first collection period at each test site.

sweating, V, varied from 0.35 to $25.3 \mathrm{gm}$. $\mathrm{M}^{2} \mathrm{~min}$. (Figure $3 \mathrm{a}$ ); therefore, the rate of excretion of potassium in the sweat, $E_{k}$, a product of the concentration and flow, increased in linear proportion to $\mathrm{V}$ throughout the entire range of $\mathrm{V}$ (Figures 4 and 5). Two of the experiments proved to be atypical in that $S_{k}$, like $S_{N a}$, rose with increase in $\mathrm{V}$ (Figure $3 \mathrm{~b}$ ), but, unlike $\mathrm{S}_{\mathrm{Na}}$, did not appear to approach a maximal value.

$S_{\mathbf{k}}$ was proportional to the concentration of potassium in plasma, $P_{k}$, which remained constant in any one experiment but ranged from 3.7 to 5.6 mEq. per L. in the total of 32 experiments. The ratio of the mean concentration of potassium in the sweat to the concentration in plasma, $\overline{\mathrm{S}}_{\mathbf{k}} / \mathrm{P}_{\mathbf{k}}$, averaged $2.2 \pm 0.48$ with a range from 1.7 to 4.2 .

The samples of sweat obtained from the period

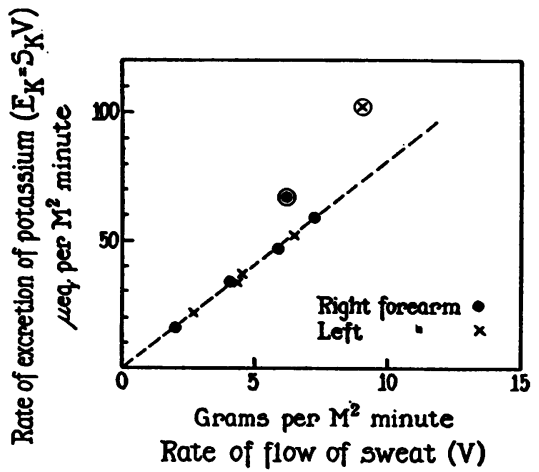

Fig. 4. Relation Between the Rate of Excretion of Potassium in the Sweat and the Sweating Rate

The data are calculated from the experiment shown in Figure 3a. An encircled point refers only to data from the first collection period at each test site.

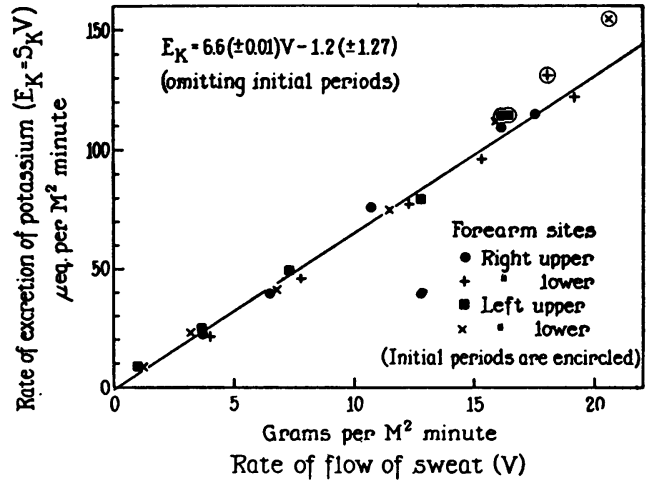

Fig. 5. Relation Between the Rate of Excretion of Potassium in the Sweat and the Sweating Rate

Data are from the same experiment as the data of Figures 1 and 2. An encircled point refers only to data from the first collection period at each test site.

immediately following the injection of Mecholyl had a higher concentration of potassium than the subsequent periods. The concentration of potassium in the sweat of 68 initial collection periods, $\overline{\mathrm{S}_{\mathbf{K}}}{ }^{0}$, averaged $10.7 \pm 2.9 \mathrm{mEq}$. per L.; excluding the data from the initial periods, the sweat potassium concentration averaged $8.9 \pm 2.5 \mathrm{mEq}$. per L. This difference proved to be significant $(\mathrm{p}<0.01)$.

The ratio of the potassium concentration in the initial sweat samples to the concentration in plasma, $\mathrm{S}_{\mathbf{K}}{ }^{0} / \mathrm{P}_{\mathbf{K}}$, averaged $2.5 \pm 0.27$ with a range from 1.9 to 4.4 . In the experiments in which 4 sites were stimulated simultaneously, the sweating rate during the initial period, Vo, varied enough from site to site to show that $S_{\mathbf{K}}{ }^{0}$ was independent of Vo.

Summation of water, sodium and potassium excretion during the entire response to stimulation

The total quantities of water, $Q_{\mathrm{H}_{2} \mathbf{O}}$, sodium, $Q_{\mathrm{Na}}$, and potassium, $Q_{\mathrm{K}}$, excreted from each site during a test were determined by adding the amounts of water, sodium and potassium obtained in the successive periods. If all the sweat following a single injection of Mecholyl were collected as a single sample, the concentration of sodium and potassium would be $Q_{\mathrm{Na}} / Q_{\mathrm{H}_{2} \mathrm{O}}$ and $Q_{\mathrm{K}} / Q_{\mathrm{H}_{2} \mathrm{O}}$, respectively. The value of $Q_{\mathrm{Na}} / \mathrm{Q}_{\mathrm{H}_{2} \mathrm{O}}$ ranged from 6.2 to $85.2 \mathrm{mEq}$. per liter, averaging $39.5 \pm 18.4$ mEq. per L. (Table II); $\mathrm{Q}_{\mathrm{K}} / \mathrm{Q}_{\mathrm{H}_{2} \mathrm{O}}$ averaged $9.4 \pm 2.5 \mathrm{mEq}$. per $\mathrm{L}$. with a range from 5.0 to $21.8 \mathrm{mEq}$. per L. (Table II). Both $\mathrm{Q}_{\mathrm{Na}} / \mathrm{H}_{2} \mathrm{O}$ 
and $\mathrm{Q}_{\mathrm{K}} / \mathrm{H}_{2} \mathrm{O}$ varied greatly from subject to subject, but very much less variation was evident in replicate experiments carried out on the same subject (Table II). In addition the variance of these parameters from site to site in the same experiment was significantly less $(p<0.01)$ than from experiment to experiment at the same site, indicating that the total variance of both $Q_{\mathrm{Na}} /$ $\mathrm{Q}_{\mathrm{H}_{2} \mathrm{O}}$ and $\mathrm{Q}_{\mathrm{K}} / \mathrm{Q}_{\mathrm{H}_{2} \mathrm{O}}$ was due predominantly to physiological and not technical factors.

The ratio of the total excretion of sodium to the total excretion of potassium, $Q_{\mathrm{Na}} / \mathrm{Q}_{\mathrm{K}}$, averaged $4.3 \pm 3.4$ with a range from 0.64 to 13.6 . In the initial period following stimulation the ratio of the excretion of sodium to the excretion of potassium, $\mathrm{S}_{\mathrm{Na}^{0}} / \mathrm{S}_{\mathrm{K}}{ }^{0}$, averaged $5.5 \pm 3.4$ with a range from 0.9 to 14.4 .

No noteworthy differences were observed when the data obtained from the normal subjects were compared with that obtained from the hypertensive patients on a high salt intake. Nonetheless it is of interest that the factor of hypertensive disease appeared to be dissociated from the factor of sodium chloride intake, since patients W. P. and A. Y., in whom the sodium chloride intake was most severely restricted ( $5 \mathrm{mEq}$. daily), were not found to have the lowest concentrations of sodium in the sweat. In fact, the lowest values of sweat sodium concentration and the highest value of sweat potassium concentration were observed in the hypertensive patients, F. McC., L. F., and M. F., in whom the salt intake was more than four times as great (22 mEq. daily).

\section{DISCUSSION}

The lower concentration of sodium in sweat as compared to plasma could occur as a result of primary movement of water by the tubular cells from the extracellular fluid to the gland lumen followed by diffusion of sodium ions insufficient to restore concentration equilibrium. If, in this schema, some of the diffusing sodium ions were to be engaged and then transported by another cellular process oriented in the reverse direction, i.e., from the forming sweat to the extracellular fluid, the sodium concentration of the sweat would be further lowered. Alternatively, if both water and sodium were transported across the tubular epithelium in one direction in one portion of the gland and in the opposite direction in another por- tion of the gland, the lower concentration of sodium in sweat relative to extracellular fluid would be a consequence of a net dominance of water transport lumenwards, and/or sodium transport in the opposite direction. A simpler explanation for the production of sweat of low sodium concentration, namely, reabsorption of sodium from an ultrafiltrate of plasma (as in the kidney), is unacceptable a priori because of the lack in the structure of the sweat gland of a filtering bed comparable to the glomerulus. Furthermore it has been shown in physiological studies that the sweat gland presents a barrier to the free diffusion from extracellular fluid to tubule lumen of small molecules that pass through the glomerular filter without hindrance (3).

In a previous paper we have suggested that a precursor solution is formed in variable amounts in the sweat glands, that a constant fraction of this solution is returned to the extracellular fluid, and, therefore, that the sweating rate is proportional to the rate of formation of precursor (2). In the present work it has been shown that the rate of excretion of sodium in the sweat, $E_{\mathrm{Na}}$, is not a linear function of the rate of flow of sweat, nor, therefore, of the rate of formation of precursor. The increment in the rate of excretion of sodium in the sweat, $\mathrm{dE}_{\mathrm{Na}}$, rises with increment in the sweating rate, $\mathrm{dV}$, and, therefore, with increment in the rate of formation of precursor. The ratio $\mathrm{dE}_{\mathrm{Na}} / \mathrm{dV}$ appears to approach a maximum limiting value, a phenomenon which is explained if it is assumed that the sweat gland forms a precursor solution of constant sodium concentration from which sodium is reabsorbed by a process of limited capacity. Under this assumption the quantity of sodium presented per unit time to the reabsorbing system, that is, the rate of input of sodium, depends on the concentration of sodium in the precursor and the rate of formation of precursor. At the lowest rates of formation of precursor, the rate of input of sodium will be less than the reabsorptive capacity, and none will appear in the sweat. With increasing rates of formation of precursor the sodium input will equal and then exceed the maximal rate of reabsorption; at this point sodium appears in the sweat collected on the skin surface. ${ }^{3}$ With fur-

\footnotetext{
3 Since the tubules may be expected to vary in functional capacity as well as size, the glands with the smallest maximal reabsorptive capacity for sodium will per-
} 
ther increase in the rate of formation of precursor the rate of reabsorption of sodium becomes a progressively smaller fraction of the rate of input of sodium and thus the rate of excretion of sodium in the sweat approaches the rate of input asymptotically. The slope of this asymptote, the maximum input of sodium per unit quantity of sweat produced, is identical with the limiting concentration of sodium, $S^{\prime}{ }_{\mathrm{Na}}$, which is approached at rates of flow exceeding $5 \mathrm{gm}$. per $\mathrm{M}^{2} \mathrm{~min}$.; the intercept, $\mathrm{T}_{\mathrm{Na}}$, can be interpreted as the maximal capacity of the glandular mechanism for reabsorption of sodium from a precursor solution (Table II).

This hypothesis has been suggested as an explanation of the relation between the concentration of sodium and the rate of flow of salivary secretion (4). The rate of excretion of sodium in parotid saliva was found to approximate a linear function of the rate of flow of saliva at flows above $1 \mathrm{ml}$. per minute. A linear regression of the rate of sodium excretion on the rate of salivary flow has a slope, $\mathrm{S}_{\mathrm{Na}}$, of $107 \pm 3.8 \mathrm{mEq}$. per liter and an intercept, $\mathrm{T}_{\mathrm{Na}}$, of $60 \pm 7.8 \mu \mathrm{Eq}$. per minute. In view of the fact that the subjects of both the saliva and the sweat studies were maintained in the same environment with similar activities, diets and daily intakes of sodium, it is of interest that the mean value of $S_{N a}^{\prime}$ for saliva was greater than any single value and approximately twice the mean value of $S^{\prime}{ }_{N a}$ for sweat. The parameter, $\mathrm{T}_{\mathrm{Na}}$, cannot be directly compared, since in the case of saliva, it is influenced by the amount of functioning parotid tissue in the gland studied, and, in the case of the sweat, it is influenced by the dimensions and density of glands in the skin area sampled.

In the case of potassium, a reabsorptive process is not suggested since the rate of excretion, $E_{K}$, was found in general to be simply proportional to the sweating rate, the curves passing through the origin (Figures 4 and 5 ).

\section{SUM MARY}

The concentrations of sodium and potassium in human sweat were measured following stimula-

mit the appearance of sodium excretion at the lowest rates of flow. This would explain the appearance of sodium in the sweat at times when the average rate of input of sodium into the glands is less than the average reabsorptive capacity. tion of sweating by local injection of acetyl B. methylcholine.

The concentration of sodium rose toward a maximum with increase in the sweating rate but was always lower than the concentration in the plasma. The mean concentration of sodium in the total output of sweat from each stimulated site ranged from 6.2 to $85.2 \mathrm{mEq}$. per $\mathrm{L}$. averaging $39.5 \pm 18.4 \mathrm{mEq}$. per $\mathrm{L}$. The concentration of sodium in the sweat obtained in the initial collection period was invariably higher than the concentration of sodium in the sweat collected in any subsequent period even when the sweating rate was lower in the initial than in the subsequent period.

The concentration of potassium in the sweat, $S_{K}$, was greater than the concentration in the plasma, $P_{K}$, the ratio $S_{K} / P_{K}$ averaging $2.2 \pm$ 0.48. In general $S_{K}$ remained constant as the sweating rate declined; exceptionally $S_{K}$ decreased with decrease in the sweating rate. The average concentration of potassium in the sweat obtained in the initial collection periods was significantly higher $(P<0.01)$ than the average concentration of potassium in the sweat collected subsequently. The concentration of potassium in the total output of sweat from each stimulated site ranged from 5.0 to $21.8 \mathrm{mEq}$. per L., averaging $9.4 \pm 2.5 \mathrm{mEq}$. per $\mathrm{L}$.

The relation of the rate of excretion of sodium and potassium to the rate of flow of sweat is compatible with the hypothesis that both ions are delivered into a precursor solution and that sodium, but not potassium, is reabsorbed by a subsequent process of limited capacity.

\section{REFERENCES}

1. Robinson, S., and Robinson, A. H., Chemical composition of sweat. Physiol. Rev., 1954, 34, 202.

2. Schwartz, I. L., Thaysen, J. H., and Dole, V. P., Urea excretion in human sweat as a tracer for movement of water within the secreting gland. $\mathrm{J}$. Exper. Med., 1953, 97, 429.

3. Thaysen, J. H., and Schwartz, I. L., The permeability of human sweat glands to a series of sulfonamide compounds. J. Exper. Med., 1953, 98, 261.

4. Thaysen, J. H., Thorn, N. A., and Schwartz, I. L., Excretion of sodium, potassium, chloride and carbon dioxide in human parotid saliva. Am. J. Physiol., 1954, 178, 155. 